Establishment contained 74,000 bibliogruphical units, including 66,000 reports of which 25,000 were on microcards. On October 1, 1960, the Library engaged a librarian to act as adviser on Russian.

The report concludes with a list of publications by members of the staff of the Cormmission and with a detailed map of the layout at the Riso Research Establishment.

Nordic Institute for Theoretical Atomic Physics

Tho third annual report of the Nordisk Institut for Teoretisk Atomfysik (NORDITA)*, which contains both Danish and English versions of the text and covers the period July 1, 1959-June 30, 1960, reports the work continued on the same lines as provious years. The organization still oporated on an interim basis, pending the working out by the committee, appointed by the Governments of the member countries (Denmark, Finland, Iceland, Norway and Sweden) and the Nordic Council, of the general * NORDITA: Nordisk Institut for 'Teoretisk Atomfysik Arsberentning 1959/60 (Annual Report). Pp. 45. (Copenhagen: NORDITA Blogdamsvej 17,1962 , principles for tho administration of joint Nordic institutions. During the year the board consisted of four members from Denmark, Finland and Norway, respectively, three from Sweden and one from Iceland, with Prof. Niels Bohr as chairman. The staff comprised Prof. C. Moller as director and four scientific and four administrative staff. Thore were fourteen research fellows, six of whom had had their fellowships extended for a second year. Eleven research fellows and a member of the staff of Nordita, together with other Danish and Swedish physicists, undertook a week's study trip to Geneva for the purpose of a visit to CERN. The report concludes with nine appendixes in which are listed the various publications and lecture notes issued by the Institute during the year; tho colloquia and courses of lectures held; the lectures given by visiting foreign physicists; the visits paid by rnember's of the staff of the Institute to other institutions and the attendance of staff and research follows at congresses and meetings; and the visits paid by the research fellows to their home institutions.

\title{
LONG-TERM PLANNING OF RESEARCH IN JAPAN
}

$I^{1}$ 1954 the Science Council of Japan, a body consisting of 210 members, formed a committee for long-term planning of research. This committee did its main work between 1954 and 1956 , but is still continuing its investigations; among its original members were the chairman (Prof. Arisawa), who is an economist, and three secretarios one an economist (Prof. Tsuru), the second an agricultural scientist (Dr. Fukushima) and the third a mathernatical statistician (Prof. Kitaguwa). The Committee was concerned with recommendations on population, food, energy, industrial techniques and fundamental sciencos.

Prof. Kitagawa has summarized, in the January issue of the Austratian Journal of Science, the White Paper on Research, published in 1956 by the Science Council of Japan, which deals with fundarnental science.

The method of investigation was that of questionnaires to individuals and institutions, issued with the co-operation of national committees in the various sciences. These consisted of two overlapping sections, the first endeavouring to obtain objective information about the departments in which the individuals concerned were working, and the second part asking for suggestions for the improvement of the departments and of Japanese scionce in general. The results were then submitted to leading experts in each field investigated, and, after this check, proposals were made to meet the problems outlined.

The recommendations were: (1) To raise the general standard of training and research in universitios and research institutes by increasing their budgets, and improving their staff position and equipment. (2) To encourage co-operation among university research workers and promote the common uses of apparatus and facilities, partly in order to avoid unnecessæry duplication of expensivo equipment. (3) 'The liquid scheme'- a proposal for the establishment of central institutes in specialized topies, which would allow the easy exchange of staff between universities and the institutes. The advantages of this scheme would bo improved communication between scientists, and considerable savings on equipment which could be located at the central institutes. (4) The uses of National Committees in respective sciences for discussion of important problems in their ficlds, and the planning of future dovelopments. (5) Availability to the public of all Governmental data and scientific publications.

The Japanese Government has already taken some steps to meet the first rocommendation, the second has been partly realized, the third has been established though with a moro moderate budget than had been proposed; recommendations 4 and 5 still nwait full implementation.

In 1959 a report entitled "The White Paper on Fundamental Science, No. 1" was brought out; this pointed out that the development of fundamental scicnce was essential to technical innovation. Japan was lagging badly in the sciences and, unless strong steps were taken, there was a danger that the country would fall farther below international levels. The White Paper contains a discussion of budgets for the pure and applied sciences, including a comparison of total expenditure for these soiences in Japan with the equivalent expenditures in the United States, the U.S.S.R., the United Kingdom and Western Germany. A comparison with these countries of the ratios: (a) budget for sciences/total Government budget, and (b) budget for sciences/total national income, showed that Japan's relative expenditure was lagging. An example was also quoted of a particular department showing that only about ono-third of the total budget set aside for the sciences, less administrative and other costs, finally found its way to the scientists themselves. A study of the numbers of scientific staff showed that, in 1957, in the Faculty of Engineering of the University of Tokyo, 72 per cent of the scientific equipment was antiquated (dating before 1925). Examination of tho research system in universitios showed that the yearly system of funds and accounts was unsuitable for long-term planning of research. Moreover, the 
Japanese 'chair system', whereby the establishment in any particular subject consists of one professor, one assistant professor and two assistants, is not entirely favourable to the pursuit of research particularly in view of the wide range of modern research work.

On postgraduate training and the numerous newly established universities, the White Paper points out that the number of staff, the budget of departments and the scientific apparatus were insufficient for postgraduate training. It was desirable to achieve high academic standards in the large number of new universities created in Japan since the end of the Second World War: these had made an effective contribution to local culture and technical education, and had produced many scientists.

Finally, recommendations were made for the increase of university salaries including the salaries of technicians and assistants, for the defraying of travel costs to conferences, for book discounts to academies, for tax deductions on donations to universities, for study abroad of Japanese scholars and their attendance at international conferences, as well as the invitation of foreign scholars to Japan, and, finally, the encouragement of universities not subsidized directly by the Government.

Some points on scientific education were discussed. In universities the separation into faculties, which is fairly rigid in Japan, was a bad principle, and departmental groupings would be preferable. Broad groupings under mathematical sciences, physical sciences, chemistry, geology and biological sciences would be better than specialized subdivisions in any of these branches. It was suggested that faculties be abolished so that a student could, for example, graduate in both engineering and mathematics if his specialized field were electronics. This is not possible at present.

The final section of the White Paper consists of comparisons, by experts in various fields, of Japanese science with science in foreign countries.

\section{WOMEN IN SCIENCE AND TECHNOLOGY}

T HE first edition of Opportunities for Girls and Women in Science and Technology was published five years ago and was in great demand, indicating that many schoolgirls, teachers, parents and employers were interested in careers for girls in the scientific and technical field. During the past five years more physics and chemistry laboratories have been built and equipped in girls' schools so that a larger proportion of girls who are interested in science have the opportunity to study it basically and prepare them selves for further specialized training. There has been a substantial increase in the number of girls taking mathematics, physies and chemistry in the General Certificate of Education at Ordinary - and Advanced-level, but still the number of young women scientists entering industry and the professions is disappointingly low. At the same time, there are women of real ability in all branches of pure science. There are now fifteen women who are Fellows of the Royal Society.

When looking for reasons for the reluctance of girls to work in the scientific field, it would still seem that there is some fear on the part of girls, and possibly also of parents, of work which is new and a little unusual. They do not realize the satisfaction to be obtained from practical scientific work at all levels. The reason why some schools have a steady flow of girls into technical positions may be because one or two older ones come back to school and talk with enthusiasm about the work they are doing, and make the younger ones interested.

The present demand for scientific manpower means that there are many opportunities for girls and women who have qualifications or who are willing to study while working. A new edition of Opportunities for Girls and Women in Science and Technology* describes the kind of professions which are now offering openings. Mathematicians are in great demand, as are physicists and chemists in laboratories. There are many special branches of science such as metallurgy, biochemistry, biophysics and physiology, which are not school subjects but which depend in the first place on the basic scientific subjects learnt at school. An introduction to these branches of science may only come at university-level, but it is the object of the booklet to indicate that such subjects exist and to point to the sources of further information about them. Engineering also falls into this category, and even now few girls take up this work. It is significant that those who enter this field do well, probably because they have to fight against a certain amount of opposition before they get established, so that only the best survive.

The booklet contains details of the many openings in different careers.

* Opportunities for Girls and Women in Science and Technology. Pp. 42. (London: British Federation of University Women, Ltd.,
1961.) 3s. 6d.

\section{ORAL POLIOVIRUS VACCINATION IN COSTA RICA}

\begin{abstract}
A $\mathbf{N}$ investigation, planned and carried out jointly A by the Yale Poliomyelitis Study Unit and the World Health Organization Regional Poliomyelitis Laboratory of the Americas, during the course of a nation-wide vaccination campaign in Costa Rica*, sought to determine the effectiveness of a trivalent oral poliovirus vaccine in immunizing young children living in a tropical environment. More specifically,

*WHO Chronicle, 16, No. 4 ; April, 1962.
\end{abstract}

its aims were to measure the rate of antibody conversion and antibody increase induced by two doses of vaccine given at a month's interval; to determine the prevalence of non-poliovirus enteroviruses in the children, and their possible inhibitory effect on the efficiency of vaccination; and to estimate the extent to which attenuated strains that had been administered spread within the families of vaccinees, and the duration of their excretion by vaccinees and 